Section Editor

Mitchell S.V. Elkind, MD, MS

Roopa Seshadri, MD

Rita Christopher, MD

H.R. Arvinda, DM

Address correspondence and reprint requests to Dr. Roopa Seshadri, Department of NIIR, Neurocentre, NIMHANS, Hosur Road, Bangalore 560029, India

drroopastjohns@gmail.com

\section{Teaching NeuroImages: MRI in infantile Sandhoff disease}

\section{Figure Brain MRI}
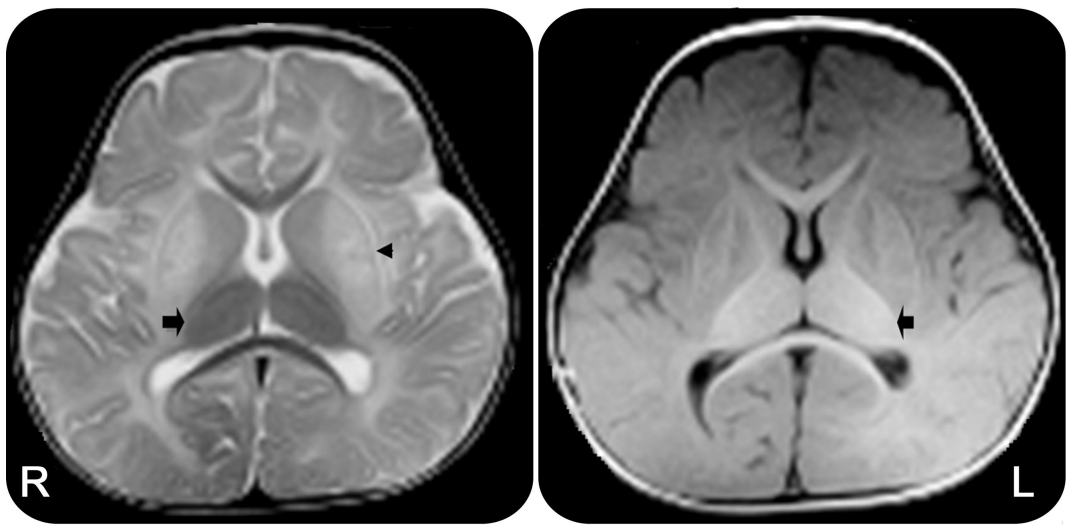

Axial T2- and T1-weighted images demonstrate bilateral symmetric thalamic T2 hypointensities, which are due to calcification associated with intracellular ganglioside deposition, and T1 hyperintensities (arrows). Bilateral putamina show T2 hyperintensities (arrowhead). There is delayed myelination indicated by T2 hyperintensities in the white matter. Corpus callosum is spared.

A 1-year-old girl, whose parents were second cousins, presented with developmental delay and regression of milestones. She had macrocephaly, generalized hypotonia, brisk reflexes, and hepatosplenomegaly. Ophthalmoscopic examination revealed bilateral macular cherry-red spots. MRI of the brain (figure) demonstrated bilateral symmetric thalamic T2 hypodensities and T1 hyperintensities with delayed myelination. Total hexosaminidase activity of serum was reduced to 86 $\mathrm{nmol} / \mathrm{h} / \mathrm{mL}$ (reference range 350-750 $\mathrm{nmol} / \mathrm{h} / \mathrm{mL}$ ), confirming the condition to be Sandhoff disease. This autosomal recessive disorder occurs as a result of deficiency of both $\beta$-hexosaminidase $\mathrm{A}$ and $\mathrm{B}$, leading to accumulation of GM2 ganglioside. ${ }^{1,2}$ Tay-Sachs disease
( $\beta$-hexosaminidase A deficiency) presents similarly but does not include hepatosplenomegaly. ${ }^{1,2}$

\section{AUTHOR CONTRIBUTIONS}

Dr. Seshadri: drafting, revising the manuscript, study concept, interpretation of data, acquisition of data. Dr. Christopher: drafting, revising the manuscript, study concept, interpretation of data, acquisition of data, study supervision. Dr. Arvinda: study supervision.

\section{REFERENCES}

1. Yun Y, Lee S. A case report of Sandhoff disease. Korean J Ophthalmol 2005;19:68-72.

2. Hittmair K, Wimberger D, Bernert G, Mallek R, Schindler EG. MRI in a case of Sandhoff's disease. Neuroradiology 1996;38(suppl 1):S178-S180. 


\title{
Neurology
}

\author{
Teaching NeuroImages: MRI in infantile Sandhoff disease \\ Roopa Seshadri, Rita Christopher and H.R. Arvinda \\ Neurology 2011;77; 34 \\ DOI 10.1212/WNL.0b013e318227b215
}

This information is current as of August 1, 2011

\section{Updated Information \& Services}

References

Subspecialty Collections

Permissions \& Licensing

Reprints including high resolution figures, can be found at: http://n.neurology.org/content/77/5/e34.full

This article cites 2 articles, 0 of which you can access for free at: http://n.neurology.org/content/77/5/e34.full\#ref-list-1

This article, along with others on similar topics, appears in the following collection(s):

All Genetics

http://n.neurology.org/cgi/collection/all_genetics

All Pediatric

http://n.neurology.org/cgi/collection/all_pediatric

MRI

http://n.neurology.org/cgi/collection/mri

Information about reproducing this article in parts (figures,tables) or in its entirety can be found online at:

http://www.neurology.org/about/about_the_journal\#permissions

Information about ordering reprints can be found online:

http://n.neurology.org/subscribers/advertise

Neurology ${ }^{\circledR}$ is the official journal of the American Academy of Neurology. Published continuously since 1951, it is now a weekly with 48 issues per year. Copyright Copyright (? 2011 by AAN Enterprises, Inc.. All rights reserved. Print ISSN: 0028-3878. Online ISSN: 1526-632X.

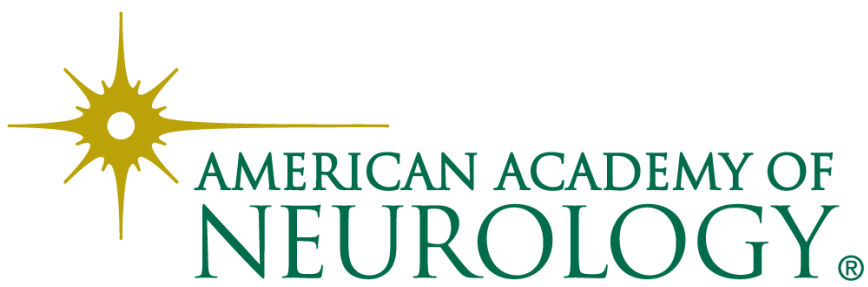

